\title{
Haemoglobinopathies and newborn haemoglobinopathy screening in Germany
}

\author{
R Dickerhoff, ${ }^{1} 0$ Genzel-Boroviczeny, ${ }^{2}$ E Kohne ${ }^{3}$
}

\begin{abstract}
${ }^{1}$ Asklepios Kinderklinik, St Augustin, Germany;

${ }^{2}$ Department of Obstetrics and Gynecology, University Hospital

Munich, Munich, Germany;

${ }^{3}$ Hemoglobin Laboratory,

University Children's Hospital,

Ulm, Germany
\end{abstract}

Correspondence to:

Roswitha Dickerhoff, Asklepios Kinderklinik, 53745 St Augustin, Germany; Roswitha.

Dickerhoff@uni-bonn.de

Accepted 9 September 2008

\begin{abstract}
Germany has been an immigration country since the early 1950s. In December 2007, 6.7 million non-German citizens lived in the country. However, the total number of citizens with a migration background is 15-20 million, about 9 million of whom come from countries where sickle cell disease and thalassaemias are frequent. In a country with 82 million inhabitants health authorities are not worried by the presence of probably 1000-1500 sickle cell and 450 transfusion-dependent thalassaemia patients, and therefore no screening or preventive measures have been taken so far on a national scale. There are plans for a pilot project (1 year) to screen all newborns for sickle cell disease in obstetric hospitals in $4-5$ cities with more than $20 \%$ migrants. Funding and lack of an infrastructure to provide counselling are major problems.
\end{abstract}

Immigration from the Mediterranean Basin to Germany started in the early 1950s, and from Africa in the early 1980s. In November 2007 (Federal Statistics Bureau in Wiesbaden) 6.7 million immigrants without a German passport were living in Germany (82 million inhabitants): 1.7 million from Turkey, approximately 820000 from Italy and Greece, 250000 from the Middle East, approximately 120000 from North Africa (Maghreb), and 110000 from Sub-Saharan Africa. However, the total number of citizens with an immigration background was 15-20 million, 9 million of whom came from countries where haemoglobinopathies and thalassaemias are frequent. Numbers of new diagnoses of sickle cell disease at the major haemoglobin laboratory in Germany (Professor E Kohne, Ulm, Germany) over the last 10 years suggest that, in 2008, at least 1000-1500 patients with sickle cell disease are living in Germany. There are 450-500 patients with transfusion-dependant beta thalassaemia. We have no figures for individuals with alpha thalassaemia syndromes.

In 1987 we established a voluntary register for paediatric sickle cell patients, provided physicians with up-to-date information about sickle cell disease and established an information centre for haemoglobin disorders. Since 1987, 582 patients with all known genotypes have been registered. In June 2008 there were 288 patients being followed at 92 hospitals or private practices in our register: $75 \%$ children, $25 \%$ adults. The majority of paediatric patients still under follow-up in the register are from Sub-Saharan Africa, while most of the registered adult patients have a Mediterranean background.

Neonatal screening for sickle cell disease is not yet done in Germany on a national level. Diagnosis depends on the astuteness and knowledge of individual physicians. As a result of our information efforts since 1987, paediatricians are fairly well informed about sickle cell disease. Young adults however face enormous problems of transition into adult medicine as very few internists are familiar with sickle cell disease.

There is one hospital in Germany (Obstetric Department, University Hospital Munich; Professor O Genzel-Boroviczeny) where limited directed neonatal screening, initiated because of a personal interest, has been done since 2004: all newborns of Sub-Saharan-African mothers are screened for sickle cell disease, without having information about carrier status of the mother, or ethnic background or carrier status of the father. From July 2004 to May 2008, 306 newborns of African mothers were screened. Heel stick blood on Guthrie cards was used and examined by highperformance liquid chromatography at the Hemoglobin Laboratory, Ulm (Professor E Kohne). One baby had sickle cell anaemia (0.3\%) and was referred to the University Children's Hospital Munich. Twent-eight babies were heterozygous carriers of haemoglobin S (9.2\%) and eight were heterozygous carriers of haemoglobin C (2.6\%). Mothers of heterozygous babies were informed about the screening result whenever they could be reached. Obviously newborns with sickle cell disease born to Turkish, Greek, Sicilian, Middle-Eastern and North African mothers would have been missed.

In Germany, screening for sickle cell disease needs to be universal, as it is impossible to elicit a precise ethnic family history for each pregnant woman and her partner. About $50 \%$ of our sickle cell patients in Germany are Caucasians from a wide spectrum of origins; many young adult carriers are third generation immigrants and there is a high rate of migrant-German intermarriage. The authors know blond and blue-eyed sickle cell carriers with German last names.

Until now sickle cell disease has not been recognised as a public health problem because of the relatively small number of sickle cell patients (1000-1500) in a country of 82 million inhabitants. There is no antenatal screening for thalassaemias and sickle cell disease. We are going to propose a pilot study to the national newborn-screening committee that includes universal newborn screening for haemoglobin disorders in obstetric services in cities with a migrant population of $>20 \%$ (Berlin, Frankfurt, Offenbach, Stuttgart, Mannheim and Munich). Difficulties to be encountered will be funding, but most of all the lack of any infrastructure for counselling parents of newborns with hemoglobin diseases or trait, as there is not yet any general awareness of haemoglobinopathies.

Competing interests: None. 


\section{JCP}

\section{Haemoglobinopathies and newborn haemoglobinopathy screening in Germany}

R Dickerhoff, O Genzel-Boroviczeny and E Kohne

J Clin Pathol 2009 62: 34

doi: 10.1136/jcp.2008.058909

Updated information and services can be found at:

http://jcp.bmj.com/content/62/1/34.full.html

\section{These include:}

References Article cited in:

http://jcp.bmj.com/content/62/1/34.full.html\#related-urls

Email alerting Receive free email alerts when new articles cite this article. Sign up in service the box at the top right corner of the online article.

Notes

To request permissions go to:

http://group.bmj.com/group/rights-licensing/permissions

To order reprints go to:

http://journals.bmj.com/cgi/reprintform

To subscribe to BMJ go to:

http://group.bmj.com/subscribe/ 